\title{
ENTREPRENEURIAL GOVERNANCE: CHALLENGES OF LARGE-SCALE PROPERTY-LED URBAN REGENERATION PROJECTS
}

\author{
TUNA TAŞAN-KOK
}

Delft University of Technology, OTB Research Institute, Jaffalaan 9, 2628 BX Delft, the Netherlands. E-mail: m.t.tasan-kok@tudelft.nl

Received: December 2007; revised October 2008

\begin{abstract}
Large-scale urban regeneration projects become highly complex as they involve multiple actors with different expectations. In general, the implementation of such projects entails building governance regimes at the city or regional level, but this often means forging partnerships between public and private actors to serve as policy instruments. Each city government formulates its own strategy for coping with the complexities of various levels of policy-making, thereby establishing multi-level governance regimes. And each city has its own particular experience with the implementation trajectory: long or short, successful or unsuccessful. This paper focuses on how the complexities of multi-actor governance influence the implementation of these projects. The purpose is to show how the macro-level institutional context affects the project's success and to analyse the challenges posed by multi-actor governance. Comparative analysis of two old port regeneration projects, namely Rotterdam's Kop van Zuid in the Netherlands, and Het Eilandje in Antwerp, Belgium, reveals how similar challenges were dealt with in different institutional contexts.
\end{abstract}

Key words: Entrepreneurial governance, urban regeneration, Rotterdam, Antwerp, project implementation, comparative analysis

\section{INTRODUCTION}

Within the framework of a neoliberal policy agenda, local authorities have been turning from the indirect promotion of entrepreneurship toward property-led urban development, whereby they encourage investment partnerships between private and public parties (Swyngedouw et al. 2002a, p. 200). The public sector usually embarks on large-scale projects in pursuit of economic and social restructuring via spatial intervention. Generally initiated by the public sector, the projects envision large-scale urban regeneration to upgrade, revitalise, or renew neighbourhoods, and also offer the kind of spatial restructuring that will attract private investment to improve the social conditions of a larger territory. Thus, private sector involvement is encouraged to stimulate capital accumulation.

A shift to entrepreneurial forms of governance involves the externalisation of state functions; up-scaling of governance to delegate selected tasks to higher levels governance; and down-scaling of governance to local practices and arrangements to incorporate new social actors to the arena of governing (Swyngedouw 2005a; p. 1998). Focusing on this third dimension of governance, this paper highlights local practices which explore the challenges of 
implementing large-scale projects in the form of a PPP (public private partnership). Several publications connect these projects to the formation of new modes of governance, to the political, economic and social power relations in the city, and also to the rise of new instruments and processes of planning (Newman \& Thornley 1996; Swyngedouw et al. 2002b; Salet \& Majoor 2005; Albrechts 2006a; Salet 2006; Taşan-Kok 2008). Others discuss the issues of social justice, participation and democracy within property-led forms of entrepreneurial governance (Moulaert 2000; Lemke 2001; Swyngedouw 2005a; Moulaert et al. 2007). Recent research projects (SINGOCOM, ${ }^{1} \mathrm{SP} 2 \mathrm{SP}^{2}$ ) have tackled the motives, processes and challenges of developing such projects throughout Europe. These projects link entrepreneurial governance practices to property-led development in a variety of frameworks, highlighting the issues of democracy and participation.

Keeping these critical viewpoints in mind, this paper explores the success and failure factors of large-scale project implementation. The capacity of a system to deal with complex challenges defines the success of the implementation (Dahl 1994). We argue that a wellorganised implementation process covers the institutional innovations from the point of spatial organisation to social innovation. However, using social and institutional innovations to ensure the success of the implementation process does not necessarily lead to success in terms of social cohesion. Exploring the development and implementation challenges of large-scale regeneration projects, this paper defines a framework in which to set out and discuss the challenges of implementation and shed a light on the complexity of multi-actor governance in the neoliberal era.

Governance cannot be defined only by the continuous exchange between public and private actors because much of the policy will take its final shape in the implementation process (Pressman \& Wildavsky 1973; Pierre 1999). Thus, the implementation process is a crucial step in the success of forms of governance in urban systems where property-led development sets the policy agenda of the local government. Successful implementation depends on harmony between the macro-level institutional context (which organises the relationships between the public and private stakeholders) and the microlevel institutional ties between individual actors. Only a well-oiled system can produce institutional innovations that are capable of simultaneously meeting the challenges and responding to the emerging needs. We consider a governance system robust when various actors demonstrate a capacity to create new modes of interaction in the event of failure, problems, or unexpected developments, all of which usually arise during the process of implementing large-scale projects.

We seek answers to the following questions:

- Which strategies are created by public stakeholders to deal with private-sector involvement? To what extent do particular strategies follow different governance systems?

- Which institutional innovations are made to deal with the divergent expectations of public and private stakeholders?

- Which weak points have led to failure of those strategies and innovations?

Here, we showcase two projects that have faced the same challenges: One in Antwerp (Het Eilandje), Belgium, the other in Rotterdam (Kop van Zuid), the Netherlands (Figure 1). ${ }^{3}$ Both projects were implemented as PPPs. Ultimately, implementation was faster, more efficient, and more influential in Rotterdam than in Antwerp. The planning and implementation processes were greatly affected by macrolevel structural differences.

Both projects seem to have had similar starting conditions but achieved totally different degrees of success. Day by day, Kop van Zuid has grown, flourished, and created a visible change in the urban landscape as well as influencing the socio-economic prospects of Rotterdam. Meanwhile in Antwerp, Het Eilandje has remained a modest, partially implemented, and fragmented project - a lonely little island, indeed. We set out to explain the difference from the institutional point of view by applying comparative analysis to investigate the effect of various social, political, and economic forces on dissimilar models of governance (Pierre 1999). Reviewing the empirical material, links were discerned between the general processes (apparent from general observation) and specific processes. In-depth interviews with key stakeholders both helped confirm the 


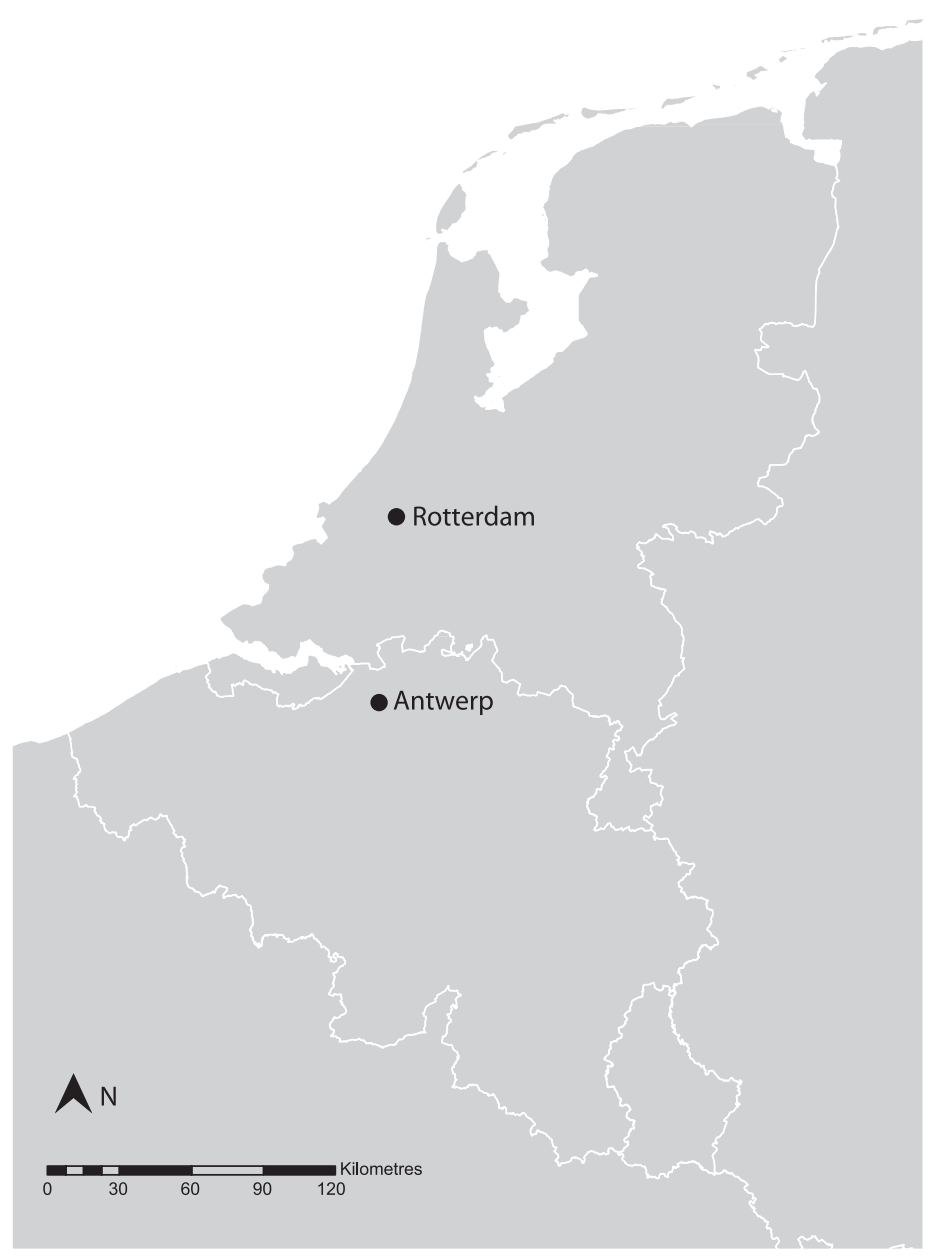

Figure 1. Antwerp and Rotterdam on the European map.

challenges and revealed the coping strategies of the stakeholders.

Here we first outline the challenges of multi-level governance within the framework of new urban policy. The subsequent section introduces the major complexities of urban regeneration in multi-actor systems that pursue a property-led course of development. The following sections compare the two projects, setting off the challenges against the coping strategies, institutional innovations, and failures. The paper concludes with a discussion of the issues.

\section{PROPERTY-LED DEVELOPMENT AND CHALLENGES OF ENTREPRENEURIAL GOVERNANCE}

Large-scale projects have become important instruments for local governments, influencing the form, function and scope of new modes of entrepreneurial urban governance (Moulaert $\&$ Seika 2003). There are diverse governance models because the differences in institutional cultures and value systems (values, norms, beliefs, practices, etc.) produce varying urban policy choices and outcomes (Pierre 1999, 
p. 375). Governance is a process of co-ordinating political decision-making (DiGaetano \& Strom 2003), as well as the actors, social groups, institutions in a particular institutional context (Melo \& Baiocchi 2006) to attain appropriate goals that have been discussed and collectively defined in the fragmented, uncertain environments (Le Gales 1998, 2001). Swyngedouw's definition of 'governance-beyond-the-state' (2005a, p. 1992) collects different discussions under the umbrella of institutional arrangements of governing, which gives a greater role to private sector actors and parts of civil society in selfmanaging what used to be provided by the national or local government. Compared to state-based arrangements in which hierarchical and top-down relations set rules in a relatively bureaucratic manner, governance-beyond-thestate rules with more participatory, inclusive, and horizontally networked relations between socio-cultural, political, and business elites where trust among the stakeholders is high, despite conflicts and oppositional agendas (Swyngedouw 2005a, p. 1995). Le Gales (2001, p. 170) describes these as policy networks, arguing that increasing political fragmentation occurs as a result of a lack of actors and organised interests or a weak integration process due to the autonomous networks. As we reveal in the following sections, the level of political fragmentation is very much related to the system's capacity to deal with complex challenges of multi-actor governance.

Numerous changes pertain to urban governance (Kearns \& Paddison 2000, pp. 845-846): increasing inter-urban competition and entrepreneurialism (see also: Harvey 1989); changing local urban culture due to homogenising global culture; unconnecting cities from the national state due to declining support of national governments; and expanding the international agenda through cross-border co-operation. The neoliberal ideology, which rests on the belief of open, competitive and unregulated markets, is behind these changes (Brenner et al. 2005). The new urban policy, being affected by deregulation of state control, downsizing of public services, the dismantling of the welfare programmes, and the enhancement of international capital mobility, calls for transformation to promote capital accumulation and to increase the comparative advantages of the city in a global inward investment economy (Brenner et al. 2005). This policy entailed a shift from 'managerial government' to a 'entrepreneurial governance', whereby the municipal government becomes a key player in urban development, cast as an active negotiating party instead of the party implementing urban development policy. This rollback neoliberalism tendency emerged especially after the 1980s in a cost-cutting form of urban entrepreneurialism as municipalities were increasingly constrained to introduce various measures to lower the costs of administration (Brenner et al. 2005). The 1990s witnessed a relatively rolled out neoliberalism tendency. Market principle dominated the political agendas of local governments, in which regulatory competence of the state shifted onto responsible and rational individuals who were encouraged to give their lives a specific entrepreneurial form (Lemke 2001; Swyngedouw 2005a, p. 1997).

After a period of heightened entrepreneurialism, the dualistic nature of property rights regimes became more obvious: On the one hand urban land and property markets have depended upon the transfer of land rents for productive purposes (commercial property development), while on the other hand governance relations have endorsed reproductive purposes (for households), which have different socio-economic logics (Jager 2003). Webster (2002) claims that the property market reproduces more visible 'clubs' as the playing field of specific actors, compared to the social forms of governance that constantly establish new sets of relations and dynamics in cities. These relations form a 'new form of governmentality' in which a particular rationality of governing is combined with new technologies, instruments and tactics of conducting the process of collective rulesetting (Foucault 1982; Swyngedouw 2005a). In this loosely defined structure, different modes of governance became more interdependent through networks and more interactions between various actors occurred at different levels (Le Gales 2001, p. 168).

The conditions and consequences of these new modes of governance have been heavily criticised as being a less democratic and elite-dominated formation of urban policy (Swyngedouw et al. 2002a). Coalitions of economic, socio-cultural or political elites drive the 
internal power choreography of systems of governance-beyond-the-state (Le Gales 2001; Swyngedouw et al. 2002a, b). In time these elite networks that shape the urban policy also change their character from professional and political elite-driven to business elite-driven networks in urban development, leading to exclusive processes. The nature of these public private partnerships (PPPs) also poses questions for democratic participation, as partnerships do not always address the normative standards by which participation should be judged (Melo \& Baiocchi 2006, p. 588).

The dynamics of the global financial sector have become crucial in the entrepreneurial shift in urban governance, setting up the foundation of the new modes of governance. The increasing mobility of capital has been articulated, managed, and integrated by ongoing financial deregulation and through this complex web of relationships. Financial deregulation brings more global financial activities into the cities, with a growing amount of portfolio investments and stock market transactions influential in the property-led urban development. The increasing share of international capital in the property market is tied to the success of financial deregulation. The high degree of financial deregulation opens up the urban property market to commodification and makes it easier for international capital to penetrate (Taşan-Kok 2004). On the other hand, the increasing amount of international capital and the rising number of actors make the property market more complex. The spatial outcome of these changes takes the form of large-scale projects that are funded, developed, and managed by international companies or partnerships. With the increasing influence of global capital movements, urban development has become more sensitive to the fluctuations of financial markets (Fainstein 1994).

Financial organisations investing in new activities unconstrained by regulatory control have increased speculation in urban development (Leyshon \& Thrift 1997). The global capital market's involvement in urban development via the fictitious capital formation in the built environment plays an important role in the success of large-scale urban regeneration (Ball 2006). Involving private investment capital seems to be an important success factor for urban governments for implementation of plans, although the long-term consequences of these projects are unclear. The public sector sees large investments in flagship projects for city marketing as a means to attract more investment capital and revitalise some sites on that basis. The interest of local property investors and developers has been an advantage for the success of this type of urban regeneration (Taşan-Kok 2004); however, the increasing dependency on global capital puts projects in jeopardy as the property market downturn intensifies with the slowing down of the global economy. Nonetheless, it should be noted that local and global markets are intertwined and without local market interest (of end-users, tenants, retailers, etc.) the availability of international investment capital will not mean much for the success of large-scale projects (TaşanKok 2004).

In this entrepreneurial and competitive environment, property-market actors take more proactive roles in urban development. They must do so because of their financial position and their partnerships in strategic projects. Balancing public and private interests in governance systems appears to pose a major challenge, and the outcome seems problematic. Examples abound of unrealistic public development schemes that failed to attract private investments, or market-oriented projects that serve very limited public interests. In governance systems like that of the Dutch, the participation of private-sector actors is organised centrally and has a seemingly better balance between public and private sector interests than the fragmented governance system of Belgium, as will be argued further on in this paper.

\section{MULTI-ACTOR SETTING AND CHALLENGES FOR IMPLEMENTING LARGE-SCALE PROJECTS}

The recent literature puts property-led multiactor development schemes in the spotlight (Swyngedouw et al. 2002b; Salet \& Majoor 2005; Albrechts 2006b; Salet \& Gualini 2006; TaşanKok 2008). Large-scale projects are seen as 'the hallmarks of new urban policy' (Van Criekingen et al. 2006). Schemes of this kind have always been on the agenda of governments but in the last 20 years there has been a drastic 
reorganisation of planning and urban policymaking structures and a rise of new entrepreneurial modes of intervention, planning goals, tools and institutions (Newman \& Thornley 1996; Swyngedouw 2005b).

In many ways, these projects became instrumental for new modes of governance as they set new relations and changed the form of the old ones between the public and private sector actors. The aims and means of large-scale projects vary from the most socially-oriented public regeneration programmes to the most capital accumulation-oriented private sectorled ones. Due to this dualism, large-scale projects are severely criticised in the literature: They often result in sponsoring high-profit sectors with few local social benefits (Moulaert 2000; Moulaert et al. 2001; Swyngedouw et al. 2002b; Weber 2002; Moulaert et al. 2003; Salet \& Gualini 2005); they also lack comprehensive, integrative and persuasive planning concepts for multiple land use to shape urban environments that balance public and private interests (Flyvbjerg 2005; Majoor 2006; Gualini \& Majoor 2007); and a high level of misinformation about costs and benefits that mislead the public seems to be a common and implicit issue, causing systematic overrun of costs and delays (Flyvbjerg 2005). Moreover, Bruzelius et al. (2002) criticise large-scale projects for their lack of mechanisms to enforce accountability, in terms of absence of clear objectives and instruments; lack of mechanisms to measure how objectives are being met; and to reward good and penalise poor performance.

Moulaert et al. (2007) put the critics within the framework of new urban policy, which is evolving towards more fragmentation, inequality and socio-economic imbalance. They suggest discussing the social outcomes of large-scale projects within the framework of social innovation $\left(\mathrm{SINGOCOM}^{4}\right)$, which broadly stated means the satisfaction of human needs through innovation in the relations within neighbourhood and community governance (Moulaert et al. 2007). Obviously, the need for a change of emphasis towards social innovation for the delivery of unsatisfied services is increasing in these projects (Moulaert et al. 2001) although it is not on the agenda of the private sector.

Despite these issues, project-led development in strategic urban locations (railway stations, or central brownfield zones) has become a popular strategy among urban governments to implement the new urban policy in concert with the private sector, and to re-enforce the competitive position of their metropolitan economies (Swyngedouw et al. 2002b, p. 542). However, it has been a complex experience. New urban policy poses many challenges for the stakeholders. Perhaps the most significant macro-level challenge is the fact that the rules and norms are not very clearly defined or agreed upon (Hajer 2003; Swyngedouw 2005a) in these new forms of governmentality. Moreover, for urban governments the greatest challenge is creating and sustaining democratic practice and social justice in the large-scale projects and creating the fair economic and social conditions that enhance democracy and empower excluded or marginalised social groups through these spatial interventions (Swyngedouw 2005a). The processes of design, development, and implementation bring about difficulties that vary from one institutional system to another. However, they have a number of key issues in common, due to the conditions created by the new urban policy and property-led urban development. We have divided these challenges into three groups (confirmed by the interviews in Antwerp and Rotterdam):

Multi-actor challenges - The multi-actor nature of the co-operation between the public and the private sector creates four major challenges in the implementation of large-scale projects.

1. Conflicting interests and competing aims of stakeholders. Conflicting and competing aims of a variety of private- and public-sector stakeholders is a common characteristic of multiactor projects. The reason is that making compromises and balancing interests takes time and energy, and thus costs money for each stakeholder (Interview with Out). Moreover, the need for a change of emphasis in social innovation for the delivery of unsatisfied services creates conflict between the public and private sector actors (Moulaert et al. 2001) as it is not on the agenda of the private sector.

2. Organisational hierarchy and need for coordinated action. The involvement of a variety of actors creates complexity, which necessitates 
co-ordination. This is especially evident in systems of governance with complex hierarchical structures. Hierarchical relations may hinder the smooth functioning of the process when public stakeholders cannot take action directly (Interview with Embrechts). Moreover, a new plural form of leadership is taking place in these projects instead of an individual one (Melo \& Baiocchi 2006, p. 593).

3. Institutional complexity and need for institutional innovation. The inclusion of a variety of actors leads to fragmented decision-making (Interview with Bakker). It also subordinates formal government structures to new institutions and agencies. This causes a redistribution of policy-making powers, competencies, and responsibilities (Swyngedouw et al. 2002a, p. 209). Institutional complexity is a common challenge in strategic projects and institutional innovations are needed to deal with complex multi-actor and multi-level relationships. Large-scale projects require specific institutional settings to create and co-ordinate a smooth-functioning coalition.

4. Shifting aims and goals of actors. Responding to changing market conditions and externalities, the aims of the actors will shift over time. This makes the whole process more complicated. Each actor has its own targets and priorities, and these may shift during the course of these large schemes. It then becomes a challenge to keep the diverse aims concentrated on the main goal of the project (Interview with Geerinck).

Planning-system challenges - The challenges in the second group concern urban planning. Planners need institutional innovations to react to the dynamic urban development agenda. Some of these challenges fall under four headings.

1. Co-ordination of plans. The shift from managerial government to entrepreneurial governance systems brings about a fragmentation of responsibilities among stakeholders. This fragmentation makes it imperative to share a common vision. Only then can the parties ensure continuity and interconnectivity in spatial developments. Even so, it seems hard to co-ordinate plans that have been formulated and issued in different tiers of the urban governmental hierarchy (e.g. zoning, development, metropolitan plans). Sometimes the authorities remain unaware of each other's plans until a problem arises in the decision-making structure (Interview with Bakker).

2. Lack of innovative instruments. Tailor-made planning instruments are needed for the implementation of large-scale projects as existing guidelines and formal planning structures are suspended due to the negotiations between the public and private parties going hand in hand with an eclectic planning style (Swyngedouw 2005c). On the one hand these innovative instruments have to accommodate specific conditions and complexities. On the other hand, they are focused on making project management a success. These instruments only serve the aim of efficient and effective implementation of strategic projects without taking their social impacts into account. Although each project has social and economic targets, the social gains are limited compared to the economic ones (Interview with Bakker).

3. Design-oriented planning. The elements of vision, concept and design are very important to the success of a strategic project. However, design alone is not forceful enough to address conflicting interests, satisfy demands, and resolve power struggles among a wide variety of stakeholders (Interview with Out).

4. Participation and acceptance. Large-scale projects have a great impact on the physical development of the wider area, but also on the social dynamics of the surrounding neighbourhoods. Depending on the scale of the development, the effects may be felt throughout the city (as in mega projects such as Olympic villages, universal Expo projects, etc.). It is especially challenging for the public sector, which is more concerned about social innovations and society's appreciation of the outcomes (Interview with Coppenrath).

Property market challenges - The third source of complexity, namely property-market dynamics, also creates some challenges. These are especially evident when the projects are of a public-led nature. The challenges fall under three headings. 
1. Redistribution of urban land rents. As Swyngedouw (2005c) points out, the increasing involvement of the private sector does not necessarily mean that private investment is greater than the public sector's financial involvement in large-scale projects. In Europe, they are generally initiated by the public sector and largely financed by state resources, with the public sector taking a great deal of risk. Large investments, however, put great stress on the public budget when urban governments are dependent on their own resources (Interview with Out). The profits are almost always collected by the private sector. Thus, financial gain is very difficult for the public sector to achieve even though large public investments are made (Flyvbjerg 2005).

2. Market uncertainty and risk. Property-market conditions and externalities create risks for large-scale projects with multiple partners. Apparently, the actors on the investment side are very cautious and want to be able to predict the risks involved. Due to economic crises or changing market conditions, largescale projects are always in danger of failure, serious delay, or a change in plan.

3. Public sector's lack of knowledge about privatesector dynamics. When a large-scale project is based predominantly on public investment, it appears to be hard to attract and maintain the interest of the private sector. Even more problematic is the public sector's limited knowledge about private-sector operations. In many PPPs, the public actor stays a passive partner, participating via landownership. In other cases, if the public actor initiates a project, the subsequent steps of development may not be clear due to propertymarket conditions of which the public actor is not aware. Obviously, knowing the market's expectations give the public sector the room to manoeuvre more efficiently and effectively (Interview with Out).

Keeping these challenges in mind, we now turn to the diverse types of entrepreneurial governance systems. To highlight the divergent reactions to the same challenges, we focus on two urban regeneration projects: Het Eilandje in Antwerp and Kop van Zuid in Rotterdam. These cases were selected for comparison because they illustrate the differences that the macro-level institutional frameworks have created.

\section{HET EILANDJE (ANTWERP) AND KOP VAN ZUID (ROTTERDAM): WHY THE DIFFERENCE?}

Due to differences in governance cultures, the urban development stakeholders established entrepreneurial modes of governance specific to each system, reflecting local contingencies in Belgium and the Netherlands. The ability of the actors to establish new modes of governance is strongly affected by local contingencies. In other words, the macro-institutional conditions, together with national differences in social, economic, and political characteristics, are reflected in urban policy at the macro level as well as in the success of collaboration at the micro level.

Belgium has a federal system whereby responsibilities are decentralised to the regions (Flemish, Walloon and Brussels). Although the hierarchy is structured well, it may be called a fragmented governance system because, in the absence of a sole authority, it relies on ad hoc organisation of relationships. In the Netherlands, by contrast, governance takes a top-down approach. There, central government and centralised public initiatives play a strong role alongside urban governments, together controlling private-sector involvement. This centrally controlled governance system combines several components: the strong centralisation tendency; the freedom to organise controlled, bottom-up participation of other stakeholders (private sector, civil society, NGOs, etc.); and widespread landownership by central and urban governments (see also: Terhorst \& van de Ven 1997). ${ }^{5}$

Belgium has a complex organisational structure: four linguistic areas (Dutch, French, German, and the bilingual Brussels area); three communities (French, Flemish, and Germanspeaking); and three regions (the Walloon, the Flemish, and the Brussels capital region). This segmentation has led to the creation of a complex set of institutions in the country (Vranken et al. 2003). There are three levels of governmental bodies: federal; community and regional (Flemish, Walloon and Brussels); and urban governments. 
The Decree on Urban Regeneration in Flanders (2002) established formal PPP structures to finance large-scale urban regeneration. The decree allows for at least 30 per cent of private investment, in addition to subsidies from the federal state, local governments, regional (now provincial) development companies, social housing companies, semi-public bodies, etc. (Van Dyck \& Verhetsel 2006). However, in the absence of a co-ordinating authority, the actors in both public and private sectors held different expectations.

The Dutch urban government system has two tiers: central government (Ministry of the Interior); and the individual local governments. Towns and cities bear primary responsibility for the implementation of urban policy. The towns and cities covered by central government urban policy are divided into two groups: first, the country's four largest cities (Amsterdam, Rotterdam, Utrecht and The Hague); second, seven secondary cities. Collaboration between the cities and the central government is organised in two ways. First, the cities are expected to formulate their own goals in a long-term development programme. Second, the central government awards special purpose grants to cities, providing five years' of financial security. Cities can spend the money freely, within designated themes, and so respond better to local conditions. Prior to 2005, cities did not have this flexibility. Thus, the role of central government is crucial to Dutch urban policy.

In the Netherlands, urban regeneration policy has taken three consecutive approaches: a physical, a social, and an integrated area-based approach. By the end of the 1990s, some aspects of urban governance were manifest in the new policy for urban restructuring. The aim of this market-oriented policy was to add expensive dwellings to the housing stock (Andersen \& Van Kempen 2003). A 'Big Cities Policy' was introduced to spur economic and social vitality through new modes of governance, particularly partnerships and networks. Its programmes entail shared responsibility and partnerships among central government and the individual city governments, contracts between cities and districts, agreements between the districts and other parties, and plans at the district/ neighbourhood level (Andersen \& Van Kempen 2003). Compared to the fragmented government competencies in Flanders, the Dutch governance system is clearly based on top-down allocation of responsibilities. Urban regeneration and the role of PPPs in this system are organised accordingly. The municipality of Rotterdam consists of autonomous organisations with certain competencies, including urban planning and development, public works, port facilities, and urban regeneration. The Rotterdam Development Corporation was set up to deal with the city's compounding regeneration issues in two ways: first, by preparing the ground for building activities; and second, by pursuing an economic policy that supports companies. In Antwerp, a semi-public organisation, VESPAAG (Autonomous Municipality for Property and Urban Projects, Antwerp) was established in the beginning of the 2000 s to manage the property owned by Antwerp city, and to make and apply urban policy on the basis of strategic urban regeneration projects carried out by PPP arrangements. VESPA not only controls the involvement of the private sector in urban development, to ensure that private actors respect public interests, but also keeps the private sector interested by easing bureaucratic procedures (Interview: Geerinck). In this respect both organisations (VESPA and Rotterdam Development Corporation) have similar backgrounds. However, the official discourse of bottom-up participation in Antwerp did not fully match actual practice, leading to distrust among various stakeholders (Christiaens et al. 2007).

\section{HET EILANDJE (ANTWERP)}

Het Eilandje (Figure 2) is an area of old docks and warehouses located fairly centrally in Antwerp. Over time, warehouses were built in small island-like clusters (eilandjes) above the docks. The suburbanisation process that began in the 1960s slowed down during the 1970s. Inner-city living became popular again, especially among the young, prompting regeneration activities in central areas. Initiated in the mid-1990s, the project has been partly developed through sporadic activities by various actors (see Table 1).

During the 1980s and 1990s, numerous residential redevelopment projects were realised in the old city centre. When much of the port 


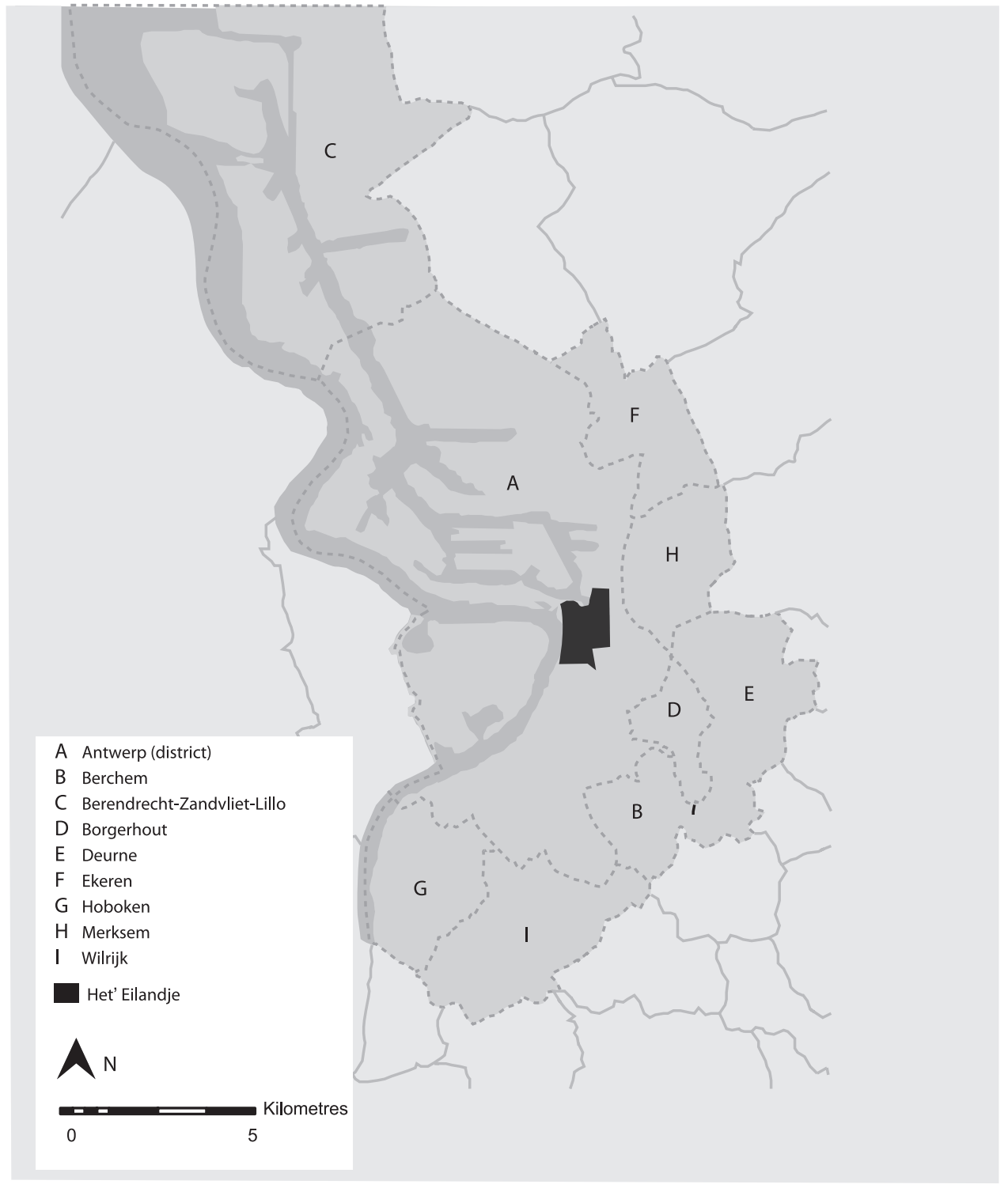

Figure 2. Location of Het Eilandje in Antwerp.

activity shifted to the north, Het Eilandje fell into decay. The derelict neighbourhood was known for its empty warehouses, low-income housing, some light industry and storage, as well as illegal activities such as prostitution. The Antwerp Port Authority is the most powerful actor in this area, owning most of the land and property there. Throughout its history, Het
Eilandje has been subject to attempts at redevelopment. In time, some scattered projects were carried out in the area, though without due attention to its historical character. During the 1980s some fragmented building activities took place, before the old warehouses and other historical buildings were declared monuments. Since the beginning of the 1990s three major 
Table 1. Stakeholders of the Het Eilandje-Antwerp.*

\begin{tabular}{ll}
\hline & Public actors \\
Local & - Antwerp City Council (civil servants, planning cell, mayor and aldermen) \\
& owns small amount of land but has the planning and permission authority and \\
& approval power \\
& - Port of Antwerp \\
& owns most of the land \\
& - Eilandje Projectbureau \\
& Buro 5 Maastricht in charge of the planning in 2000, then it became the project office \\
& - AG VESPA \\
Provincial & Managing the land and property ownership of Antwerp City \\
Regional & - Province of Antwerp \\
National & landowner of some plots at the river side, their role is limited \\
& - Federal Government \\
& urban policy, distribution of Federal State funds and small land ownerhisp \\
Profit & Private sector actors \\
& - IDEA-Consult BV (consultant) \\
& - vzw Pensioenfonds (Port authority's pension funds that caused the financial crisis) \\
& - Buro 5 Maastricht (masterplan Eilandje) \\
& - Atelier JPLX (urban design/image quality) \\
Non-profit & - R\&S (developer Montevideo warehouses) \\
& - Project 2 (developer of 6 residential towers in Westkaai) \\
& - Studio 6 (Urban development plan Antwerp) \\
& - Various construction and architecture firms \\
& Citizen groups
\end{tabular}

* The number of stakeholders (especially in the private sector) may actually be larger in reality. The information is collected from scattered resources by the author (interviews, websites and newspapers) to display the general outline and variety of the stakeholders.

planning activities have taken place to develop a master plan for solving the problems of the area with a macro level vision (Stad aan de Stroom City on the Stream Plan, approved in 1993; Mens en Ruimte-People and Space Plan, approved in 1998; and Buro 5 Maastricht - Provincial Spatial Structure Plan, approved in 2002). The first two plans were relatively design-oriented, missing economic and social innovations as well as implementation instruments.

The latter plan aimed to impose a PPP structure connecting public authorities with private parties to jointly realise the project and had the general purpose of physical, economic, and social regeneration of a declining urban waterfront neighbourhood. Inspired by Docklands in London, the Buro 5 Maastricht Plan proposed 172 hectares of new development in the area to create new living, working and cultural activities. The current master plan proposes two phases of development. The first contains three projects: South Eilandje - Oudedokken, West Eilandje - Montevideo, and East Eilandje Cadixwijk. The second phase contains two potential projects on the north side of the development area: Droogdokkeneiland and Mexico-eiland (Figure 3).

Due to differences in expectations and conflicting interests among the public-sector parties, the project had a lengthy development history (Interview with Pellens) and, as a result, the regeneration of this central zone was seriously delayed. The Antwerp city government wanted to redevelop the area to maximise public use and protect the structure of the old ports. The port authority, in contrast, wanted to maximise its profits from the redevelopment due to pressing financial troubles concerning the pension payments of port workers (Interview with Coppenrath). In order to solve this 


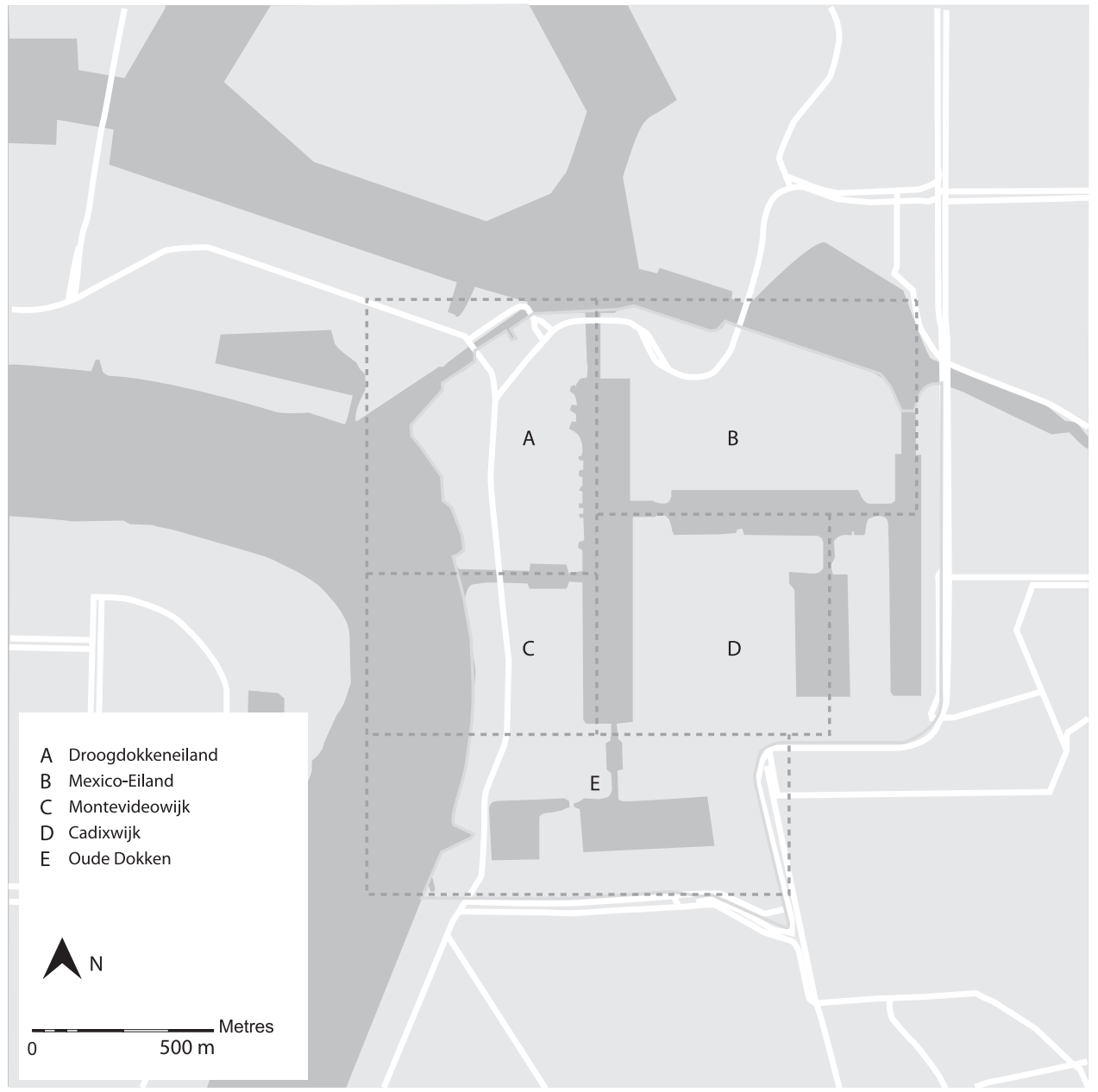

Figure 3. Planning zones in Het Eilandje.

problem Antwerp city decided to leave the ownership rights of Het Eilandje to the port authority and let them generate profit to improve their financial situation. However, in time this situation worked against the city. The port authority approach was to sell off the plots of land and property as soon as possible and leave the development activity and planning bureaucracy to private stakeholders, whereas the city wanted to redevelop the old port area with maximum emphasis on public use and protection of the old structure (Interview with Embrechts). Since the regulatory arrangements were slow, the port authority announced the sale of three large lots and property on those lots in 2003 without waiting for the city to agree. The city, on the other hand, argued that enhancing the quality of the space will raise prices in the area. Therefore, they wanted the private parties to contribute in the organisation of the public space (Interview with Pellens). However, the regulatory organisation was not sophisticated enough to implement these ideas. With mounting disagreements between the two public bodies the project bureau sought various solutions to facilitate co-operation between the port and the city (Interview with Pellens).

Some of the disagreements were dissolved in time, leading to the realisation of some scattered projects in the area such as a media centre in 
Hangar 26, the Sint Felix archives, the Koninklijk Entrepot residential project, a luxurious yachting marina in the Willemdok and a social marina in the Kempischdok (for boat houses), as well as the Gouden Anker social housing project. Construction of the main attraction of Het Eilandje, the new MAS (Museum on the Stream), finally began in the mid-2000s and the disagreement on the redevelopment of historical Montevideo warehouses is about to be solved (Interview with Dieryck). Although the Port tendered the redevelopment of the warehouses to a project developer without gaining the prior agreement of the city, an agreement between the developer (R\&S) and the city seems finally to have been reached (Interview with Dieryck).

\section{KOP VAN ZUID (ROTTERDAM)}

Rotterdam's Kop van Zuid project (Figure 4) has similar characteristics, but its outcome differs somewhat from Het Eilandje's. The varying implementations of these projects may be explained from many perspectives but the major reason lies in the differences between the two macro-level institutional frameworks and governance cultures.

Kop van Zuid is an urban regeneration project (covering 125 hectares) comprised of dock basins, former port-related businesses, and warehouses. Its objective is to redevelop the neighbourhoods around the old port areas and connect parts of the city that were spatially divided (by the River Maas) and socially disconnected. Just as in the case of Het Eilandje, once the port activities moved out of this central location, urban renewal became necessary. However, in contrast to Het Eilandje, this project was part of a larger plan to revitalise Rotterdam as a whole and to create a new marketable image for the city (Interview with Bakker). Thus, the project was initiated as a top-down renewal programme and envisioned a high quality, mixed-use area, with striking architecture and a lively waterfront. The goal was to upgrade the neighbourhoods and replace the old port functions with new land uses. By connecting the area directly to the city

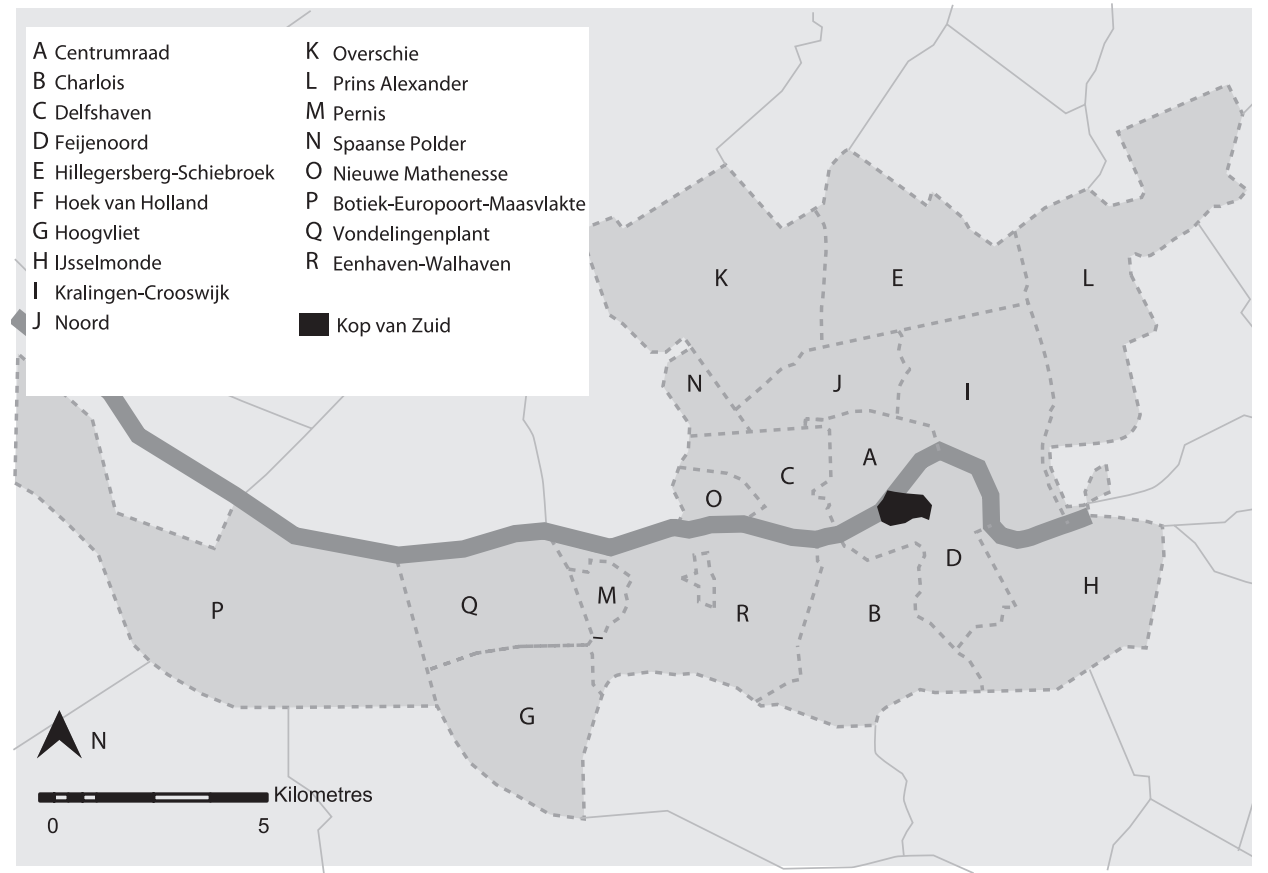

Figure 4. Location of Kop van Zuid in Rotterdam. 
centre, the programme was supposed to change Rotterdam's image and open up the entire south side of the city. The project has a principle strategy to promote local and regional economic redevelopment by attracting new actors (residents and companies) from outside the project area and direct surroundings (Miedema et al. 2002).

To tackle the run-down neighbourhoods, some plans had been drawn up to redevelop the area for social housing. The first plans of the early 1980s failed due to the conflicts of interest between private port enterprises and the city authorities (Miedema et al. 2002). Then, with the 1986 master plan (commissioned by the new director of city planning, Riek Bakker), Kop van Zuid became the key to unlock the city's huge potential (Interview with Bakker). The city council revised the plan in 1989 to satisfy the demand by PVDA (Dutch Labour Party) to include a social programme to combat unemployment (Miedema et al. 2002). The zoning plan was approved in 1991 by the city council and the national government agreed to this plan in 1994. It was adopted by the national government in 1994. Again, as opposed to the continual disagreement between the Belgian public authorities in the case of Het Eilandje, there was remarkable consensus between the Dutch government and the city of Rotterdam in the Kop van Zuid. When, for instance, the city council signed a contract with the national government that allowed and obliged it to construct the spatial infrastructure, houses and offices in the area, the national government committed itself to giving financial support to the project (Miedema et al. 2002). Meanwhile, the government also agreed to pay some $€ 15$ million for a new bridge across the River Maas. The Erasmus Bridge was completed in 1996 and has since become an iconic symbol of Rotterdam (Urbed 2006). The Kop van Zuid scheme successfully mixed diverse functions: residential, commercial, educational and leisure uses (Interview with Out). Commissioning world famous architects to design several new structures, such as the Erasmus Bridge, increased the attractiveness of the area. In addition, putting in a new metro station and a new tram line between parts of the city that had been separated - socially, economically, and physically - has connected them to each other as well as to the city centre.
The implementation process of Kop van Zuid involved more interaction between the public and private stakeholders (Table 2) compared to Het Eilandje. The plan was divided into eight main planning zones (see Figure 5) and several projects were foreseen for each zone. The co-ordination, tendering and development of these project zones were realised in the form of PPPs established by the local government and involved parties. Public and private parties joined forces to share the costs and profits on the basis of predetermined agreements (Miedema et al. 2002).

Following the main strategy of the project the Kop van Zuid area housed flagship projects that not only changed the landscape of the city but also initiated some social processes in and around the area. Despite the inclusion of some social housing in the project the new and expensive housing attracted the high income groups, isolating the area within the surroundings. As a result, the plan was revised in 1994. The new retail and office facilities also had an impact on the balance of employment in the city.

\section{CHALLENGES IN THE DEVELOPMENT AND IMPLEMENTATION OF HET EILANDJE AND KOP VAN ZUID PROJECTS}

Let us now consider how stakeholders in both projects have been dealing with the challenges (Table 3). Due to the macro-institutional differences (and specificities of the market conditions), public and private stakeholders have had to deal with different challenges in both projects. For instance, the public stakeholders in Het Eilandje had to deal with the compromise and communication issues between the main public stakeholders (Interview with Embrechts). In contrast, the public actors in the Kop van Zuid project were dealing with issues related to private-sector involvement, planning and social returns (Interview with Out). Again, the privatesector actors, who were fairly passive in the development of Het Eilandje, had to deal with constantly changing conditions due to disagreements between the public stakeholders. In the Kop van Zuid project, the private stakeholders (developers, construction companies, etc.) were dealing with the usual property market risks and negotiations. The implementation of both projects was affected by these factors. 
Table 2. Stakeholders of the Kop van Zuid-Rotterdam.*

\begin{tabular}{|c|c|}
\hline \multirow{9}{*}{ Local } & Public actors \\
\hline & $\begin{array}{l}\text { - Rotterdam City Council (mayor, aldermen, municipal executive, department of urban } \\
\text { planning and housing) }\end{array}$ \\
\hline & - OBR City Development Corporation \\
\hline & - Dutch Railway Company \\
\hline & Used part of Kop van Zuid as a shunting place \\
\hline & - Port of Rotterdam (Gemeentelijk Havenbedrijf) \\
\hline & - Rotterdam Transport Company \\
\hline & - Communications Team (project management) \\
\hline & - Quality Team (project management) \\
\hline \multirow[t]{5}{*}{ National } & - Dutch government \\
\hline & Large City Policy programme to upgrade deprived areas \\
\hline & - Department of Transportation and Public Works (funding) \\
\hline & - Department of Housing, Spatial Planning anf the Environment (funding) \\
\hline & Private sector actors \\
\hline \multirow[t]{14}{*}{ Profit } & - Teun Koolhaas and Riek Bakker (urban plan) \\
\hline & - National Investment Bank \\
\hline & - Number of international architectural (including Benthem Crouwel, Tangram, \\
\hline & Van den Broek \& Bakema, Fumi Hoshino etc) and financial consultants (NEI \\
\hline & Nederlands Economisch Institute) \\
\hline & - Bouwfonds MAB Ontwikkeling (developer De Rotterdam Wilhaminapier) \\
\hline & - Zeeuwse housing corporations (developer Stadswonen Kristal) \\
\hline & - Bouwbedrijf de Vries and Verburg (developer Cite, Hogeschool Inholland) \\
\hline & - OVG Project Development (developer Maastoren) \\
\hline & - Van Ginneken Vastgoed (developer Pakhuismeesteren) \\
\hline & - Multi Development (developer together with OVG Development for UWV) \\
\hline & - Rabo Real Estate and Johan Matser Project Development (developers Wilhelminapier \\
\hline & Zuidzijde) \\
\hline & - ING Real Estate \\
\hline \multirow[t]{5}{*}{ Non-profit } & - Erasmus University \\
\hline & - PVDA (left-wing labor party) \\
\hline & - Federation of Fejenoord Resident's organizations \\
\hline & - The Shopkeepers Association \\
\hline & $\begin{array}{l}\text { - Mutual Benefit (or Social Return) Study Group (established to implement the Mutual } \\
\text { Return programme) }\end{array}$ \\
\hline
\end{tabular}

* The number of stakeholders (especially in the private sector) may actually be larger in the reality. The information is collected from scattered resources by the author (interviews, websites and newspapers) to display the general outline and variety of the stakeholders.

Recalling the three groups of challenges identified earlier (multi-actor challenges, planning system challenges, property market challenges) we can now summarise the reactions of various actors to the challenges in each project. Their reactions fall under three headings: coping strategies; institutional innovations; and failures (Table 4):

In Rotterdam, the property development sector is sufficiently advanced to draw the interest of local and international property-market actors in this project (Table 2). Thus, although Kop van Zuid was developed mainly on public land, the project offered good opportunities for private property investment (Interview with Vries). In fact, the private-sector actors had been involved from the beginning. Development of Het Eilandje, on the other hand, was not directed primarily towards the property market by the city authorities. 


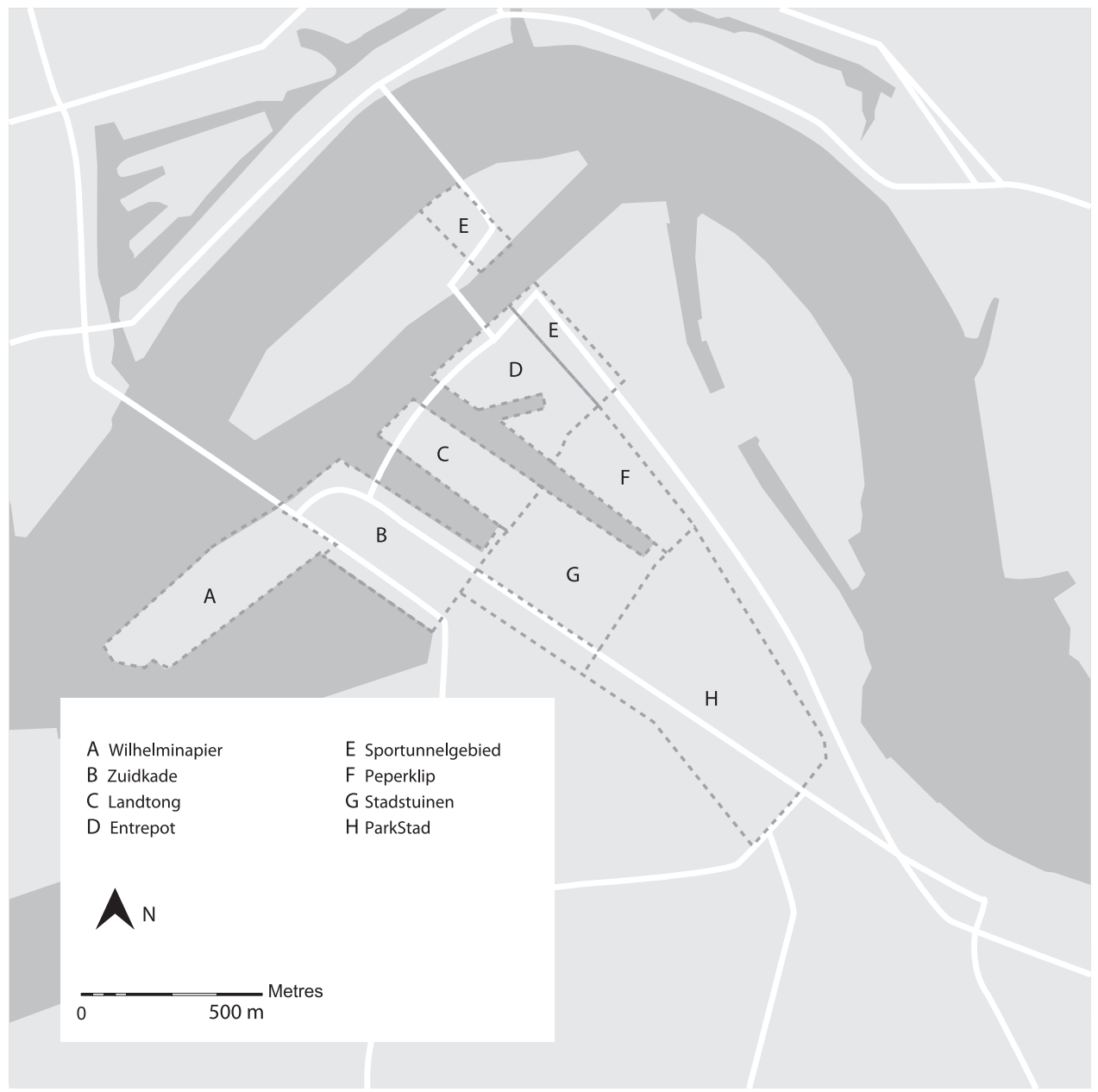

Figure 5. Planning zones in Kop van Zuid.

Table 3. Challenges of the implementation of Het Eilandje and Kop van Zuid projects.

Project name Challenges for the public stakeholders

Het Eilandje Communication and agreement on common goals

Kop van Zuid - Attracting the private sector Property-market risks - Planning a complex scheme sector stakeholders
Challenges for the private Challenges for the residents

Dealing with changing - Social polarisation due conditions due to public to the elitist characteristics sector's uncertainty of the project

- No participation until recently

- Social polarisation due

to the elitist characteristics of the project

- Limited participation 


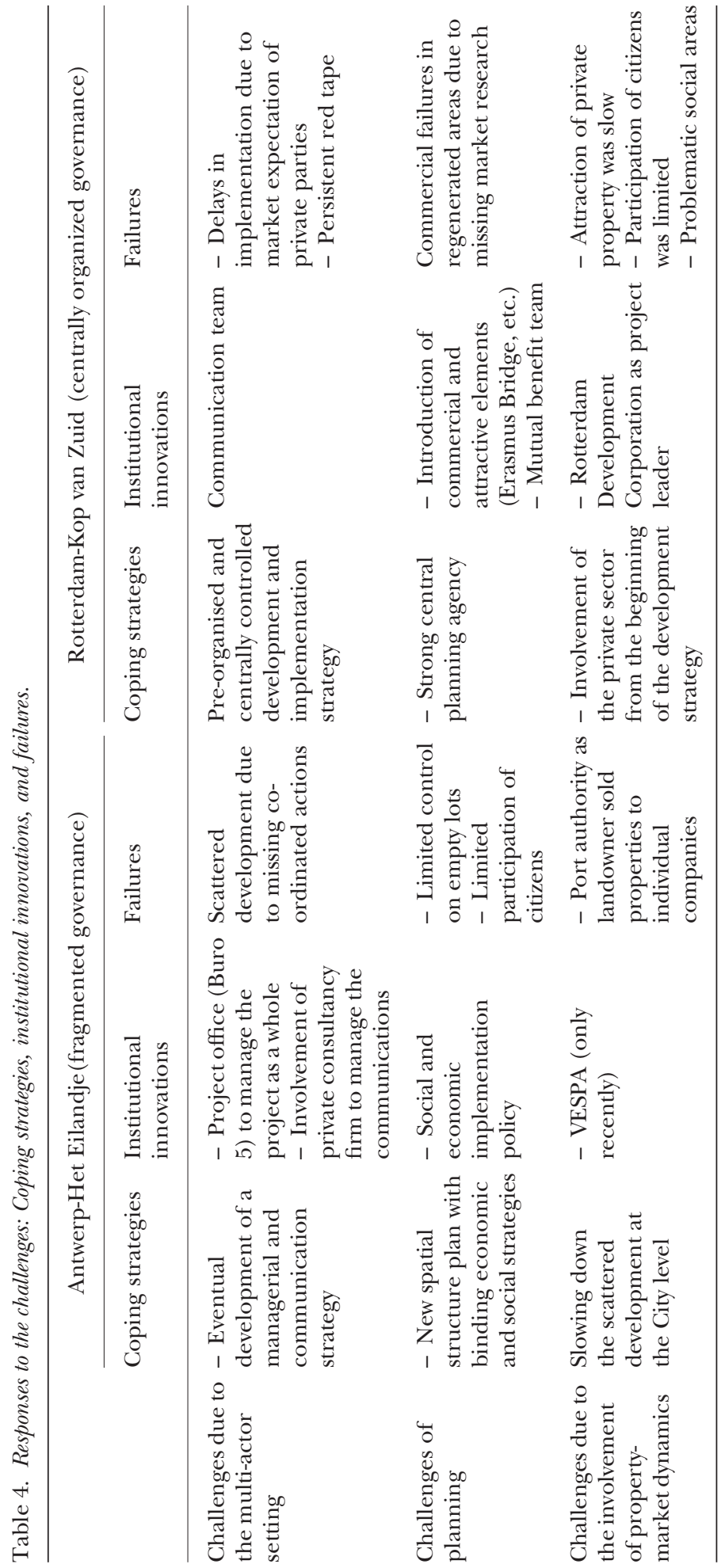


Nonetheless, private property development and profit-making on the basis of land ownership were the only concerns of the port authority, owner of most of the land. The property development and investment sector in Belgium is not as advanced and internationalised as in the Netherlands. In Antwerp, they could only attract private investment in an opportunity-driven and fragmented way.

Another external factor in the case of Rotterdam was the involvement of a key planning actor, Riek Bakker. Her role was that of an entrepreneurial public planner and director of the planning team. This strongly centralised and 'one-voice' approach is characteristic of the Dutch system. Moreover, the city council had the final decision in every stage of the project, whereas in Het Eilandje the port authority took independent decisions before getting the consent of the city even though there was no agreement as to the final decisionmaker. Another externality is that the Kop van Zuid project was perceived by central and local governments as an important instrument to change the identity of Rotterdam from an industrial port city to an international and competitive global city.

\section{REACTIONS TO THE CHALLENGES: COPING STRATEGIES AND INSTITUTIONAL INNOVATIONS}

Kop van Zuid dealt with complexity through sophisticated institutional innovation and welldefined strategies. It seems to have resolved issues by strong, centralised public-sector intervention. Het Eilandje, in contrast, has been at the centre of enormous disputes, which have caused delays and adjustments in the development process. The obstacles reflect conflicts of interest between two public stakeholders, namely the port authority and Antwerp city, over incompatible decisions on land use and competition for land rents (Taşan-Kok 2003). The problems arising during the implementation of Het Eilandje cannot be explained by any simple fact. Rather, the problems accumulated during the project's long history, dating back to the early 1990s. From the very beginning, the scheme was perceived as a design problem, and the institutional setting was therefore not geared to full co-operation between public and private stakeholders. Accordingly, the challenges arising from the involvement of multiple actors were not taken into account at the outset, which means that effective solutions were not offered until recently.

Various designs were prepared for Het Eilandje from the mid-1990s to the beginning of the 2000s. Two of these plans (the Morales and the Mens en Ruimte plans) were eventually discarded in light of budget issues and an unrealistic or incomplete implementation strategy (Interview with Coppenrath). Awaiting a more realistic design concept and underpinned by a PPP management strategy, the whole venture was abandoned, except for some small-scale projects of individual developers. The final plan (by Buro 5 of Maastricht) was prepared in detail in order to solve the urban design issues. It also introduced a model for implementing projects in PPP form with an integrated approach to development in the whole area. Therefore, the project office also acted as mediators in negotiations between various public parties. The final plan seemed realistic compared to the previous two and introduced such flexible planning tools as the Special Plan (Bijzonder Plan van AanlegBPA). Yet it could not solve the problems caused by the differing expectations of the public authorities (Taşan-Kok 2003).

On the other hand, the Kop van Zuid was initiated as part of a centrally organised plan. Thus, its implementation strategy has already considered possible problems, such as communication between public and private partners. A communication team was set up at the beginning to make sure that collaboration between stakeholders was not hindered by misunderstandings. The team has been a very important institutional innovation in that respect. Compared to Het Eilandje, where the lack of transparency in communications between different actors caused many problems, the Kop van Zuid has an open and transparent communication style. In Het Eilandje, the Project Bureau contracted a private consultancy company (IDEAConsult) to find solutions for communication and collaboration between public partners before getting the private parties involved (Interview with Embrechts).

The Kop van Zuid project is managed directly by Rotterdam City Council. Several public authorities are also involved (see Table 2). It is 
co-ordinated by a project team, including a communications team and a mutual benefit team. The project manager reports to a council steering committee, which also oversees the external quality team. The latter approves development proposals and advises on all aspects of design (Urbed 2006). Although it has been a 'crowded' partnership, it was open to wider participation. The Director of the City Planning Department, Riek Bakker, took steps to make it attractive not only to the private sector butalso to central government (Interview with Bakker). Her objective was to obtain more financial support by promoting the project 'for the good of the country as whole' (Urbed 2006). One institutional innovation involved setting up an independent quality team to ensure a high standard of development, which was deemed crucial to improving the city's image and attracting capital.

In the social dimension, some good practices are noteworthy in the Kop van Zuid project: a social return programme (SRP) to create jobs for the people in the project area; and a 'Cleaner, Safer, Greener' (Opzoomeren) campaign to encourage residents to take responsibility for their street (Urbed 2006). Interestingly, this idea was not on the agenda of the first plan, but came about through the reactions from residential organisations. In that respect the project was responsive to local needs. Within the framework of the SRP, each company involved was commissioned by the city to investigate the possibilities for hiring the long-term unemployed. Small and mediumsized businesses were also encouraged to generate new employment and do what they could to increase public safety (Miedema et al. 2002).

Het Eilandje has also generated some physical and social upgrading, especially in its southern part, closer to the city centre. For instance, new housing and commercial activity around the new headquarters of the Antwerp Port Authority (AMCA) have given the area an up-market impetus even if it was purely the port authority's initiative. The Antwerp city social planning programme is also supporting rapid regeneration. This programme cleaned up the area and since then new restaurants and cafes have opened in places that once housed prostitution (Interview with Dieryck).
In contrast to the profit-driven motive for initiating the high-rise residential development of the port in Het Eilandje, the Kop van Zuid's strategy was focused clearly on attracting highincome groups to previously dilapidated areas to enhance the upgrading odds and attract people from beyond the adjacent neighbourhoods. In so doing, it also paid attention to providing social housing $(50 \%)$, although this strategy served the higher brackets rather more; the share of affordable housing remained at 30 per cent (Miedema et al. 2002). An important institutional innovation is to use this kind of measure to create a better mix of social and expensive housing.

Another important success factor of Kop van Zuid compared to Het Eilandje was the availability and top-down organisation of public funds. As well as the PPPs in various parts of the project set up by the Development Corporation to attract private investment, central government departments also subsidised the project.

\section{FAILURES}

The case of Het Eilandje shows that a lack of transparency in the plans of the port authority and Antwerp city made private-sector participation sporadic and opportunistic. Due to the financial crisis, the port authority in Antwerp was not inclined to participate in a complicated PPP structure. Instead, they preferred to sell off pieces of land and property to the private sector. Since regulatory arrangements were slow in coming, the port authority went ahead in 2003 and announced the sale of three large lots and the properties on them. This move implies that at the time there was still none of the envisioned co-operation between the two public authorities. The project office contracted a private consultancy to heal the communication breakdown between the public parties (Interview with Embrechts). However, the project office's legal authority is limited in comparison to the landownership power of the Port Authority. Since ongoing disputes between the public authorities have kept the project office busy, citizen participation has been lagging behind expectations - yet another sign of failure.

The implementation problems of Kop van Zuid have not been as big as those encountered 
with Het Eilandje. One reason may be the topdown, pragmatic planning approach taken in Rotterdam. However, despite innovative instruments such as the Social Return Programme, the elitist nature of the project did lead to some social polarisation. The long-term employment programme did not work very well at first, as developers could not be forced into employing the unemployed (and unqualified) people. The Job Centre, which gave training to unemployed people, did not generate large numbers of employed (Miedema et al. 2002). Later on the strategy shifted towards a plan for long-term employment to attract unemployed from adjacent districts. However, the impact of this move has not been significant (Miedema et al. 2002). Moreover, some retailers suffered from the competition caused by new supermarkets developed within the framework of the project (Miedema et al. 2002).

\section{CONCLUSIONS}

Dense networks, fuzzy institutional arrangements, ill-defined responsibilities and ambiguous political objectives and priorities characterise the loosely defined structure of entrepreneurial governance (Mayer 2000; Le Gales 2001; Swyngedouw 2005a). The difference between the successful outcome of the projects Het Eilandje and Kop van Zuid illustrates the consequences of loosely structured governance arrangements for the implementation of large-scale projects. In Antwerp the ambiguity of tasks and co-ordination issues between the public partners caused delays whereas in Rotterdam the implementation was successful because of the top-down organisation of tasks and role definitions. Kop van Zuid made use of various social and institutional innovations (Social Return Programme, quality team, communication team, etc.) to reap the maximum benefit from the project in terms of marketing and social regeneration. However, commercial success did not mean success in terms of social cohesion. Vranken (2004) argues that social cohesion has a spatial dimension (at the city and neighbourhood levels) and that high social cohesion at the city level is more directly obtained in a context of low cohesion at the lower levels (areas, neighbourhoods). Similarly, Kearns and Forrest (2000) emphasised that strong ties between people within communities may lead to social, racial, and religious conflicts between those who belong to the communities and those perceived as outsiders. It means that if certain social groups concentrate in certain areas their internal cohesion will certainly be fostered but at the expense of their integration at a higher level as it will also increase the risk of exclusion both for individuals from those highly cohesive communities and of these communities from the rest of society. However, if nonconflicting relations between these diverse groups could be structured at lower levels (neighbourhood or area), a high social cohesion is possible in the urban system as a whole (Vranken 2004, p. 8). Looking from this perspective, the Kop van Zuid project clearly and rapidly changed the social landscape of the area to a more high-end residential (and business) district, decreasing the social cohesion and isolating the area from the surrounding neighbourhoods.

This is interesting because Het Eilandje, not being that successful in terms of urban planning and project implementation, shows a relatively smooth social transformation as the fragmented governance structure reflects the fragmented spatial development of the area. Due to its organisational issues, Het Eilandje developed at relatively slow speed (with fragmented development) up until the beginning of the 2000s and perhaps because of that, its social polarisation is less visible compared to Kop van Zuid. The main principle of the Kop van Zuid project to encourage 'outsiders' had a great impact on changing the local dynamics. Later, however, on discovering the increasing isolation of this exclusively designed and socially and economically 'upgraded' area from its surrounding neighbourhoods, Rotterdam city began investing in the development of the nearby neighbourhoods as one of its main objectives (Interview with Vries).

Entrepreneurial governance does not mean that pre-defined, planned and co-ordinated modes of governance will happen. While the main items on the policy agenda are dealt with by local government, other items (especially to do with property-led development projects) occur if there is a development opportunity. As the case of Antwerp shows, if the institutional 
system is unable to meet challenges during the policy implementation process, modes of governance will dissolve.

Swyngedouw (2005a, p. 1996) argues that the relative boundaries between the state, civil society and market vary. The Antwerp case demonstrates that governance-beyond-the-state requires more explicit role definition for stakeholders. In Antwerp, neither the Belgian property market was suitable (or ready) for such a shift nor were the roles of the public stakeholders clearly defined. This means that the way the relationship between the market, state and civil society is established needs further analysis. Furthermore, state-based arrangements and governance-beyond-the-state happen simultaneously. There is no clear distinction or shift from one to another. Different forms of governance occur in various forms while some statebased arrangements still take place the way they did in Antwerp.

Centralisation of control and organisational power in the public sector (at either central or urban government levels) is conducive to successful entrepreneurial governance. This is manifest in a better organisation of relationships between public and private stakeholders, a more effective implementation process for plans, and a controlled but effective involvement of property-market dynamics. However, the question remains open: even if projects are successfully implemented with the help of social and institutional innovations, is the social isolation created by these elitist projects avoidable?

Swyngedouw (2005a, p. 1993) argues that socially innovative arrangement of governancebeyond-the-state is 'Janus-faced as the democratic character is increasingly eroded by the encroaching imposition of market forces that set the rules of the game'. Looking from the democratic political governance perspective, the new modes of governance in large-scale projects mark a shift from political elite-driven processes to business elite-driven processes, which change the power geometries and citizenship relations. The impact of large-scale projects should not only be assessed at the level of surrounding neighbourhoods but at the level of a city as a whole to reduce the social polarisation caused by these new modes of governance.

\section{Acknowledgements}

The first version of this paper was presented in April 2007 at the AAG (Association of American Geographers) Conference in San Francisco. The author wishes to thank the anonymous referees and Nancy Smyth van Weesep for their useful comments and suggestions.

\section{Notes}

1. Social Innovation, Governance and Community Building, co-ordinated by IFRESI-CNRS, Lille and GURU/APL, University of Newcastle upon Tyne.

2. Spatial Planning to Strategic Projects, co-ordinated by ASRO, Catholic University of Leuven.

3. In Dutch Het Eilandje means 'Little Island' and Kop van Zuid means 'South Head'.

4. Six indepth interviews were conducted in 2003 with the public stakeholders of the project. The interviews are used as a qualitative material to check the challenges that the author has listed on the basis of her knowledge (and secondary information resources) on the two projects. During the interviews, the author asked questions in three main categories of challenges. The answers are reported without interference, as well any discussions of the larger issues of implementation which took place during the interview.

List of interviewees:

Tom Pellens, IDEA Consultants, Consultant (Interview on Belgian urban policy and regeneration strategies, 15 July 2003); Griet Geerinck, AG VESPA, urban development coordinator (Interview on AG VESPA and urban regeneration strategy in Antwerp, 29 July 2003); Katrien Embrechts, Project Bureau Het Eilandje, process manager (interview on the project's planning and development history7 November 2003); Maud Coppenrath, consultant planner, Antwerp Municipal Government, Spatial Organisation and Planning Office (interview on the planning system and organisational structure of the municipality, 26 January 2004); Maarten Dieryck, planner, City of Antwerp (Interview on the new developments on Het Eilandje, 19 September 2008); Rob N.M. Out, real estate project manager, OBR City Development Corporation, City of Rotterdam (Interview on Rotterdam's planning strategy and the planning and implementation of the Kop van Zuid project, 5 May 2004); Prof. Riek Bakker, supervisor of Kop van Zuid Project, Riek 
Bakker Advies (Interview after her presentation on Kop van Zuid at the Kop van Zuid Project Office, 17 September 2004); Isabelle Vries, port real estate (interview on the new developments on Rotterdam Port, 23 September 2008).

5. SINGOCOM: Social Innovation, Governance and Community Building research project (Moulaert et al. 2001, 2007).

6. Terhorst and Van de Ven (1997) emphasised the contradiction between Dutch and Belgian governance systems by calling the Belgian urban governance system (in the case of Brussels) 'fragmented' and the Dutch one as 'consolidated' governance (in the case of Amsterdam).

\section{REFERENCES}

Adair, A., J. Berry, S. McGreal, L. Sykora, A. Ghanbari-Parsa \& B. Redding (1999), Globalization of Real Estate Markets in Central Europe. European Planning Studies 7, pp. 295-305.

Albrechts, L. (2006a), Shifts in Strategic Spatial Planning? Some Evidence from Europe and Australia. Environment and Planning A 38, pp. 1149-1170.

Albrechts, L. (2006b), Bridge the Gap: From Spatial Planning to Strategic Projects. European Planning Studies 4, pp. 1487-1500.

Andersen, H.T. \& R. VAn Kempen (2003), New Trends in Urban Policies in Europe: Evidence from the Netherlands and Denmark. Cities 20, pp. 77-86.

Bachmann, M. (2006), Berlin-Adlershof: Local Steps into Global Networks. In: W. SALET \& E. GUALINI, eds., Framing Strategic Urban Projects: Learning from Current Experiences in European Urban Regions, pp. 115-146. Oxford: Routledge.

BALL, M. (2006), Markets and Institutions in Real Estate and Construction. Oxford: Blackwell.

Brenner, N., J. Peck \& N. Theodore (2005), Neoliberal Urbanism: Cities and the Rule of Markets. DEMOLOGOS working paper, University of Newcastle.

Brenner, N. \& N. Theodore (2005), Neoliberalism and the Urban Condition. City 9, pp. 101-107.

Bruzelius, N., B. Flyvbjerg \& W. Rothengatter (2002), Big Decisions, Big Risks. Improving Accountability in Mega Projects. Transport Policy 9, pp. 143-154.

Christiaens, E., F. Moulaert \& B. Bosmans (2007), The End of Innovation in Urban Development Strategies? The Case of Antwerp and the Neighbourhood Development Association 'Bom'. European Urban and Regional Studies 14, pp. 238-251.
DAHL, R. (1994), A Democratic Dilemma System Effectiveness versus Citizen Participation. Political Science Quarterly 109, pp. 23-34.

Digaetano, A. \& E. Strom (2003), Comparative Urban Governance: An Integrated Approach. Urban Affairs Review 38, pp. 356-395.

Fainstein, S. (1994), The City Builders: Property, Politics and Planning in London and New York. Oxford: Blackwell.

FlyvbjeRG, B. (2005), Machiavellian Megaprojects. Antipode 37, pp. 18-22.

Foucault, M. (1982), The Subject and Power. In: H. Dreyfus \& P. Rainbow, eds., Michael Foucault: Beyond Structuralism and Hermeneutics, pp. 208-226. Brighton: Harvester.

Gualini, E. \& S. Majoor (2007), Innovative Practices in Large Scale Urban Development Projects: Conflicting Frames in the Quest for 'New Urbanity'. Planning Theory and Practice 8, pp. 297-318.

Hajer, M. (2003), Policy without Polity? Policy Analysis and the Institutional Void. Policy Sciences 36, pp. 175-195.

Harvey, D. (1989) From Managerialism to Entrepreneurialism: The Transformation in Urban Governance in Late Capitalism. Geografiska Annaler B 71, pp. 3-17.

Hubbard, P. \& T. Hall (1998), Introduction. In: P. Hubbard \& T. Hall, eds., The Entrepreneurial City: Geographies of Politics, Regime and Representation, pp. 1-27. Chichester: Wiley.

JAGER, J. (2003) Urban Land Rent Theory. International Journal of Urban and Regional Research 27, pp. 233-249.

Kearns, A. \& R. Forrest (2000), Social Cohesion and Multilevel Urban Governance. Urban Studies 37, pp. 995-1017.

Kearns, A. \& R. PAdDison (2000), New Challenges for Urban Governance. Urban Studies 37, pp. 845-850.

LE GALEs, P. (1998), Regulations and Governance in European Cities. International Journal of Urban and Regional Research 22, pp. 482-506.

Le Gales, P. (2001), Urban Governance and Policy Networks: On the Urban Political Boundedness of Policy Networks. A French Case Study. Public Administration 79, pp. 167-184.

Lemke, T. (2001), The Birth of Bio-politics - Michel Foucault's Lecture at the College de France on neo-liberal Governmentality. Economy and Society 30, pp. 190-207.

Leyshon, A. \& N. Thrift (1997), Money/Space: Geographies of Monetary Transformation. London: Routledge. 
Majoor, S. (2006), Conditions for Multiple Land Use in Large-scale Urban Projects. Journal of Housing and the Built Environment 21, pp. 15-32.

Mayer, M. (2000), New Social Movements in European Cities, from the 1970s to 1990s. In: A. Bagnasco \& P. Le Gales, eds., Cities in Contemporary Europe. Cambridge: Cambridge University Press.

McGreal, S. (1999), Globalization, Localization, Markets and Property Research. Professional lecture delivered at University of Ulster. 13 April, 1999, Jordanstown.

Melo, M.A. \& G. Baiocchi (2006), Deliberative Policy and Local Governance: Towards a New Agenda. International Journal of Urban and Regional Research 30, pp. 587-600.

Miedema, F., G. Oude Engberink \& P. VAn der A.A. (2002) Rotterdam, the Netherlands: Kop van Zuid, URSPIC (Urban Development and Social Polarisation) research report retrieved from <http:// www.ifresi.univ-lille1.fr/SITE/URSPIC/URSPIC/ Rotterdam/Rotterdam.html> on 30 July 2008.

Moulaert, F. (2000), Globalization and Integrated Area Development in European Cities. Oxford: Oxford University Press.

Moulaert, F., F. Martinelli, S. Gonzales \& E. Swyngedouw (2007), Introduction: Social Innovation and Governance in European Cities: Urban Development between Path Dependency and Radical Innovation. European Urban and Regional Studies 14, pp. 195-209.

Moulaert, F., A. Rodriguez \& E. Swyngedouw (2003), The Globalized City: Economic Restructuring and Social Polarization in European Cities. Oxford: Oxford University Press.

Moulaert, F., E. SAlin \& T. Werouin (2001) Euralille: Large-scale Urban Development and Social Polarization. European Urban and Regional Studies 8, pp. 145-160.

Moulaert, F. \& F. Seika (2003), Territorial Innovation Models: A Critical Survey. Regional Studies 37, pp. 289-302.

Newman, P. \& A. Thornley (1996), Urban Planning in Europe: International Competition, National Systems, and Planning Projects. London: Routledge.

Pierre, J. (1999) Models of Urban Governance: Institutional Dimension of Urban Politics. Urban Affairs Review 34, pp. 372-396.

Pressman, J.L. \& A. Wildawsky (1973), Implementation. Berkeley, CA: University of California Press.

SALET, W. (2006), Framing Strategic Urban Projects:
Learning from Current Experiences in European Urban Regions. In: W. Salet \& E. Gualini, eds., Framing Strategic Urban Projects: Learning from Current Experiences in European Urban Regions. Oxford: Routledge.

Salet, W. \& E. Gualini (2006), Framing Strategic Urban Projects: Learning from Current Experiences in European Urban Regions. Oxford: Routledge.

Salet, W. \& S. Majoor (2005), Reshaping the Urbanity in Amsterdam Region. In: W. SALET \& S. Majoor, eds., Amsterdam Zuidas: European Space. Rotterdam: 010 Publishers.

Swyngedouw, E. (2005a), Governance Innovation and the Citizen: The Janus Face of Governancebeyond-state. Urban Studies 42, pp. 1991-2006.

Swyngedouw, E. (2005b), A New Urbanity? The Ambiguous Politics of Large-scale Urban Development Projects in European Cities. In: W. SALET \& S. Majoor, eds., Amsterdam Zuidas: European Space. Rotterdam: 010 Publishers.

Swyngedouw, E. (2005c), A New Urbanity? The Ambiguous Politics of Large-scale Urban Development Projects in European Cities. In: W. SAlet \& S. Majoor, eds., Amsterdam Zuidas: European Space. Rotterdam: 010 Publishers.

Swyngedouw, E., F. Moulaert \& A. Rodriguez (2002a), Neoliberal Urbanization in Europe: Large-scale Urban Development Projects and the New Urban Policy. In: N. Brenner \& N. Theodore eds., Spaces of Neoliberalism: Urban Restructuring in North America and Western Europe, pp. 195-229. Malden, MA: Blackwell.

Swyngedouw, E., F. Moulaert \& A. Rodriguez (2002b), Neoliberal Urbanization in Europe: Large-scale Urban Development Projects and the New Urban Policy. Antipode 34, pp. 542-575.

TASSAN-KoK, T. (2003), Brownfield Redevelopment in Antwerp: Cases from Het Eilandje Project. In: G. BARTA, ed., Brownfield Rehabilitation in Big European Cities. Budapest: Hungarian Academy of Sciences (CRSHASBP) Publications (in Hungarian).

TAŞAN-KoK, T. (2004), Budapest, Istanbul and Warsaw: Institutional and Spatial Change. Delft: Eburon.

TAŞAN-KoK, T. (2008), Urban Regeneration via Large-scale and Public-led Strategic Projects: Complex but Necessary? In: M. SITAR, ed., Urban Futures: Challenges and Opportunities for Cities and Regions. Maribor: University of Maribor, Faculty of Civil Engineering Press.

Terhorst, P. \& J. VAN DE VEN (1997), Fragmented Brussels and Consolidated Amsterdam: A Comparative Study of the Spatial Organization of Property Rights, 
Netherlands Geographical Studies No. 223. Vranken, J. (2004), Changing Forms of Solidarity: Amsterdam: Netherlands Geographical Society.

Urbed (2006), Kop van Zuid Case Study, Making Connections: Transforming People and Places in Europe. Retrieved from <http://www.urbed. co.uk/> on 4 April, 2007.

Van Criekingen, M., C. Guisset \& C. VandermotTEN (2006), Brussels Tour and Taxis: Entrepreneurship versus the Fragmented City. In: W. SALET \& E. Gualini, eds., Framing Strategic Urban Projects: Learning from Current Experiences in European Urban Regions, pp. 146-172. Oxford: Routledge.

Van Dyck, B. \& A. Verhetsel (2006), Revisiting Government's Role in the Production of Large Scale Urban Redevelopment Projects in Flanders. Unpublished Paper for the Urban FUTURE Programme.

Urban Development Programmes in Europe. In: Y. Kazepov, ed., Cities of Europe. Changing Contexts, Local Arrangements, and the Challenge to Urban Cohesion, pp. 255-276. Oxford: Blackwell Publishing.

Vranken, J., P. De Decker \& I. Van Nieuwenhuyze (2003), Urban Governance, Social Inclusion and Sustainability: National Context Reports. UGIS Working Paper. Garant, Antwerp.

Weber, R. (2002), Extracting Value from the City: Neoliberalism and Urban Redevelopment. Antipode 34, pp. 372-396.

Webster, C.J. (2002), Property Rights and the Public Realm: Gates, Green-belts and Gemeinshaft. Environment and Planning B 29, pp. 397-412. 